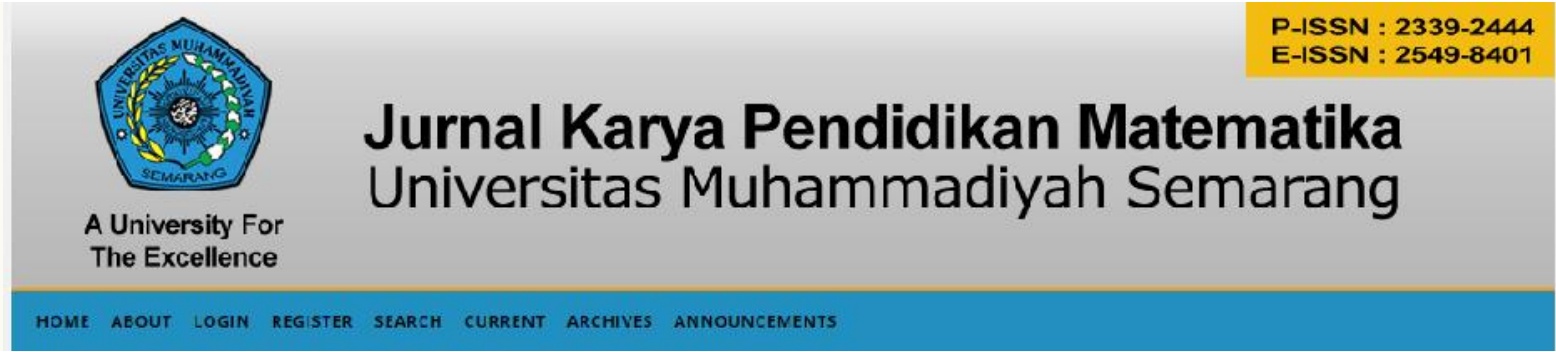

\title{
KEEFEKTIFAN MODEL STUDENT TEAM ACHIEVEMENT DIVISION (STAD) DAN E- LEARNING PADA MATERI OPERASI PENJUMLAHAN DAN PENGURANGAN PECAHAN DI SEKOLAH DASAR
}

\author{
Oleh: Sri Kadarwati ${ }^{1}$, Kasni Astutik ${ }^{2}$, Edi Prayitno ${ }^{3}$ \\ skadarwati@ecampus.ut.ac.id; kasniastuti@gmail.com: edip@ecampus.ut.ac.id \\ ${ }^{1,2,3}$ FKIP Universitas Terbuka
}

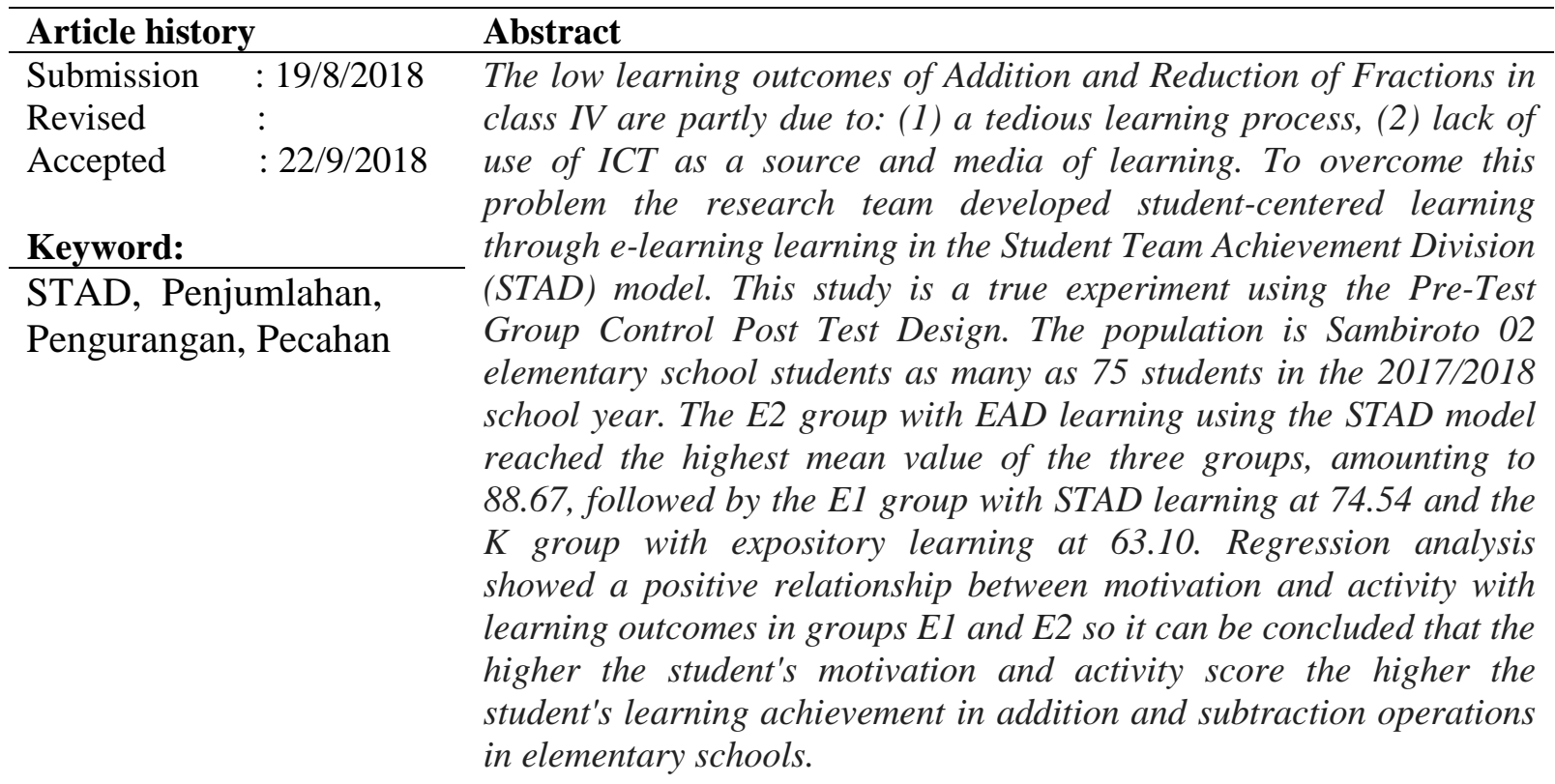

\section{Pendahuluan}

Penelitian ini dilatarbelakangi oleh anak yang lahir pada tahun 1995 hingga tahun 2014 termasuk anak generasi $\mathrm{Z}$ (generation net). Generasi ini sudah terbiasa berkomunikasi menggunakan internet, seperti melalui Facebook, Twitter, Whatshap, dan Blackberry. Mereka hidup dalam budaya serba cepat sehingga tidak tahan dengan hal-hal yang lambat. Mereka sudah sering mengerjakan dua kegiatan atau lebih dalam waktu yang bersamaan. Misalnya pada saat mereka mengerjakan Pekerjaan Rumah (PR), mereka juga sambil berbicara dengan teman melalui telepon genggam dan chatting dengan teman lewat Facebook. Mereka anak-anak budaya instan yang serba ingin berhasil dalam waktu cepat. Mereka sudah terbiasa dengan internet, maka model pembelajarannya harus menggunakan teknologi modern itu.

Matematika sebagai disiplin ilmu turut andil dalam pengembangan dunia teknologi yang kini telah mencapai puncak kecanggihan dalam mengisi berbagai dimensi kebutuhan hidup manusia yang disebut dengan era global. Di mana dalam era global tersebut telah terjadi revolusi teknologi yang ditandai dengan kemajuan teknologi informatika, industri otomotif, perbankan, dan dunia bisnis lainnya. 
Teknologi Informasi dan Komunikasi (TIK) dewasa ini berkembang cepat dari waktu ke waktu. Oleh karena itulah para cerdik-cendekia sepakat pada suatu argumen, bahwa informasi memudahkan kehidupan manusia di berbagai bidang, termasuk bidang pendidikan.

Setiap manusia tidak bisa lepas dari bidang pendidikan yang sebenarnya juga merupakan kegiatan informasi, bahkan dengan pendidikanlah, informasi tentang ilmu pengetahuaan dan teknologi dapat disebarluaskan kepada generasi penerus suatu bangsa. Melihat betapa besar peran matematika dalam kehidupan manusia, bahkan masa depan suatu bangsa, maka sebagai guru kita harus selalu berusaha meningkatkan pembelajaran dan hasil belajar. Apalagi kenyataan di lapangan menunjukkan bahwa hasil belajar matematika selalu berada di tingkat bawah dibandingkan dengan mata pelajaran lainnya.

Hal tersebut juga terjadi di SDN Sambiroto 02, berdasarkan data hasil ulangan harian matematika Kelas IV pada Rabu, 07 Februari 2018 materi Operasi Penjumlahan dan Pengurangan Pecahan hanya mencapai rerata 57,8 dan hanya $50 \%$ siswa yang mencapai nilai $\geq 60$. Pencapaian ini masih di bawah Kriteria Ketuntasan Minimal yang ditentukan yaitu 70 . Dari data hasil pengamatan guru pada proses pembelajaran matematika menunjukkan bahwa sebagian besar siswa terlihat jenuh mengikuti pembelajaran. Penyebabnya antara lain guru hanya menggunakan metode ceramah dan latihan soal secara individual, tidak ada interaksi antara siswa yang pandai, sedang, dan normal. Sebagian besar siswa memperlihatkan raut muka tidak ceria saat mulai pembelajaran matematika, tugas tidak selesai pada waktunya, dan secara sembunyi-sembunyi lebih suka melakukan kegiatan lain.

Upaya peningkatan kualitas belajar siswa senantisa dilakukan oleh lembaga pendidikan yang di antaranya dengan pemanfaatan perangkat teknologi. Pengembangan pendidikan menuju e-learning merupakan suatu alternatif dalam meningkatkan standar mutu pendidikan. E-learning merupakan suatu penggunaan teknologi internet dalam penyampaiaan pembelajaran dengan jangkauan luas. E-Learning memiliki beberapa kelebihan, antara lain: (1) memiliki kemampuan untuk memperbaharui, menyimpan, mendistribusikan, dan membagi materi ajar atau informasi dalam jangkauan yang tidak terbatas (2) pengiriman sampai ke pengguna terakhir dilakukan dalam hitungan detik, (3) memfokuskan pada pandangan yang paling luas tentang pembelajaran di balik paradigma pembelajaran tradisional (Triyono, 2012). Pemanfaatan ELearning menuntut persiapan yang matang sehingga dapat memberikan manfaat yang maksimal untuk peningkatan kualitas belajar. Analisis diperlukan menyangkut tersedianya perangkat pembelajaran, khususnya komputer, listrik, jaringan internet, dan sofware-nya.

SD Negeri Sambiroto 02 sedang berupaya memanfaatkan teknologi informasi ini dalam kegiatan belajar mengajarnya. Model pembelajaran E-Learning mulai diaplikasikan sejak awal tahun pelajaran 2017/2018 dengan harapan dapat meningkatkan kualiatas belajar mengajar yang pada akhirnya dapat meningkatkan kualitas individu siswa. Selain menggunakan e-learning, para guru juga didorong untuk menerapkan berbagai model pembelajaran yang inovatif dan melibatkan para siswa secara aktif selama prosesnya, antara lain model Student Team Achievement Division (STAD).

Model pembelajaran STAD merupakan salah satu model pembelajaran kooperatif yang dikembangkan berdasarkan teori belajar Kognitif-Konstruktivis yang diyakini oleh pencetusnya Vygotsky memiliki beberapa keunggulan. Salah satu keunggulan STAD adalah mendorong terbentuknya fungsi mental dan sosial yang lebih tinggi pada diri siswa melalui kegiatan berkomunikasi dan kerjasama antar individu (Depag RI, 2014). Pengelompokkan siswa secara heterogen berdasarkan kemampuan matematis akan memunculkan proses interaksi yang positif dalam menyelesaikan masalah. Melalui proses kerja sama semua siswa tanpa terkecuali akan mampu menyelesaikan masalah. Kelompok dikatakan belum tuntas bila ada salah satu anggotanya yang belum menyelesaikan tugasnya.

\section{Metode Penelitian}

Populasi penelitian ini adalah siswa kelas IV SD Negeri Sambiroto 02 Semarang sebanyak 75 siswa yang secara umum berkemampuan sama. Ketiga kelas dalam pembelajaran sehari-hari diampu oleh tiga guru yang berbeda namun menggunakan silabus kurikulum yang sama dan besar tingkat ketuntasan yang sama. Sampel diambil secara acak dari tiga kelas yang berbeda. Kelas yang pertama memperolah pembelajaran dengan 
model STAD, kelompok kedua diberi pembelajaran dengan model E-Learning, sedangkan pada kelompok ketiga diberikan pembelajaran dengan metode ekspositori. Ketiga kelas dilibatkan dalam ekperimen Control group pre-test post-test design (Arikunto, 2014).

Di awal analisis data, data diupayakan dipastikan berdistribusi normal dan memiliki besaran varian yang dapat dikategorikan sama secara signifikan. Langkah ini dimaksudkan bahwa semua siswa yang akan memperoleh perlakuan dalam kegiatan eksperimen memiliki kemampuan awal yang sama. Setelah melalui ketiga jenis proses pembelajaran yang berbeda, hasil belajar dianalisis untuk memperoleh gambaran hasil ketiga pembelajaran yang berbeda. Hasil pembelajaran yang dianalisis berupa hasil belajar dalam ranah berpikir kognitif.

Selain dilakukan analisis hasil belajar dalam ranah kognitif, juga dikumpulkan dan diolah data ranah afektif, yaitu tingkat aktivitas siswa selama proses pembelajaran dan kadar motivasi siswa yang melandasi aktifitas mereka. Data ranah afektif diungkap melalui penyebaran angket.

\section{Hasil Penelitian dan Pembahasan}

Penelitian dilaksanakan di SDN Sambiroto 02 Semarang yang berpedoman pada Silabus dan Rencana Pelaksanaan Pembelajaran yang telah disusun. Hasil penelitian secara deskriptif dapat dipaparkan sebagai berikut. Pada kelompok eksperimen pertama ( $\left.\mathrm{E}_{1}\right)$ hasil mean pencapaian indikator aktivitas belajar secara klasikal sebesar $77,032 \%$ artinya aktivitas belajar yang dimiliki siswa tinggi dan hasil mean pencapaian indikator motivasi belajar secara klasikal adalah 70,59 \% artinya motivasi belajar yang dimiliki siswa cukup.

Pada kelompok eksperimen kedua $\left(\mathrm{E}_{2}\right)$ hasil mean pencapaian indikator aktivitas belajar secara klasikal adalah 85,14 \% artinya aktivitas belajar yang dimiliki siswa tinggi dan hasil mean pencapaian indikator motivasi belajar secara klasikal pada kelompok eksperimen $\mathrm{E}_{2}$ adalah 84,27 \% artinya motivasi belajar yang dimiliki siswa tinggi. Berdasarkan pengamatan pada kelompok kontrol (K) aktivitas siswa kurang maksimal dan motivasi siswa sangat rendah.

Nilai rata-rata hasil belajar kelompok eksperimen $\quad\left(\mathrm{E}_{1}\right) \quad$ sebesar 74,54. Hasil belajar kognitif yang dicapai adalah nilai minimum 60 dan nilai maksimum 88 . Sehingga telah mencapai KKM yang ditetapkan dan ketuntasan belajar secara klasikal sebesar $75 \%$ tercapai. Nilai rata-rata hasil belajar siswa pada kelompok eksperimen $\left(\mathrm{E}_{2}\right)$ sebesar 88,67 dengan klasifikasi nilai baik. Hasil belajar kognitif yang dicapai adalah nilai minimum 76 dan nilai maksimum 100. Sehingga mencapai KKM yang ditetapkan dan ketuntasan belajar secara klasikal sebesar $75 \%$ tercapai.

Nilai rata-rata hasil belajar siswa pada kelompok kontrol (K) sebesar 63,10 dengan klasifikasi nilai kurang. Hasil belajar kognitif yang dicapai adalah nilai minimum 52 dan nilai maksimum 76. Berdasarkan kolom Cumulative Percent, $72,5 \%$ siswa mendapat nilai $\leq 67$. Sehingga tidak mencapai KKM dan ketuntasan klasikal tidak mencapai $75 \%$.

Pada kelompok E ${ }_{1}$ berdasarkan analisis regresi, variabel motivasi mempunyai hubungan linear terhadap hasil belajar. Juga terdapat hubungan positif, artinya antara aktivitas dan motivasi mempunyai hubungan linier terhadap hasil belajar. Pada kelompok $\mathrm{E}_{2}$ berdasarkan uji analisis data dengan regresi ganda, ada hubungan yang berarti antara aktivitas dan motivasi terhadap hasil belajar. Juga ada hubungan yang positif artinya aktivitas dan motivasi mempunyai hubungan linier terhadap hasil belajar.

Uji normalitas data pada variabel dependent (hasil belajar) ini dilakukan dengan uji Kolmogorov-Smirnov. Hasilnya variabel hasil belajar pada kelompok eksperimen maupun kelompok kontrol berdistribusi normal. Uji homogenitas dilakukan untuk menguji apakah hasil belajar dari ketiga kelompok mempunyai varian yang sama. Hasil uji homogenitas menunjukkan bahwa hasil belajar ketiga kelompok tersebut memiliki varians yang sama.

Berdasar analisis data pada tabel ANOVA disimpulkan bahwa ketiga kelompok (dua kelompok eksperimen dan satu kelompok kontrol) memiliki rata-rata hasil belajar yang berbeda atau tidak sama, dengan kata lain penggunaan perlakuan yang berbeda secara signifikan menghasilkan rata-rata hasil belajar yang berbeda pula.

Hasil belajar siswa dengan model pembelajaran STAD apabila dibandingkan dengan hasil belajar siswa dengan E-Learning berbeda secara signifikan. Hasil belajar siswa dengan menggunakan E-Learning pada kelompok eksperimen kedua $\left(\mathrm{E}_{2}\right)$ terhadap hasil 
belajar siswa dengan model ekspositori pada kelas kontrol $(\mathrm{K})$ berbeda secara signifikan. Kelompok eksperimen kedua $\left(\mathrm{E}_{2}\right)$ dengan $E$ learning lebih baik daripada kelompok eksperimen pertama $\left(\mathrm{E}_{1}\right)$ dengan model pembelajaran STAD. Dan kelompok eksperimen pertama $\left(\mathrm{E}_{1}\right)$ lebih baik daripada kelompok kontrol (K) dengan model pembelajaran ekspositori.

Skor motivasi dan aktivitas pembelajaran e-learning bermodel STAD menunjukkan skor yang tertinggi di antara ketiga model pembelajaran. Pembelajaran e-learning yang baru diterapkan di SD 02 Sambiroto Semarang berhasil menarik perhatian siswa karena langkah-langkah belajarnya merupakan hal yang baru bagi siswa. Dengan belajar di hadapan laptop para siswa selalu menanti langkah berikutnya selama proses pembelajaran. Ketertarikan pada langkahlangkah pembelajaran dan belajar di hadapan laptop memotivasi mereka untuk selalu berkonsentrasi dan memberikan semangat melakukan tugas-tugas yang dihadapinya.

Di awal pembelajaran guru menekankan bahwa kemampuan menjumlahkan dan mengurangkan pecahan menjadi tanggung jawab kelompok. Tidak boleh ada anggota kelompok yang tidak dapat melakukan operasi penjumlahan dan pengurangan pecahan. Tanggung jawab bersama ini memberi semangat para siswa untuk belajar dan berlatih di luar proses pembelajaran sebagai bekal mereka membimbing bila ada teman satu kelompok yang kurang bisa melakukan operasi bilangan pecahan. Hasil pengamatan dan hasil analisis jawaban siswa diperoleh fakta bahwa semua siswa dapat melakukan operasi bulangan pecahan. Kesalahan menyelesaikan soal bukan diakibatkan karena mereka tidak menguasai langkah penyelesaian operasi penjumlahan dan pengurangan pecahan, melainkan kekurangtelitian dalam menjumlah, mengurangkan, mengalikan dan menentukan bilangan kelipatan persekutuan terkecil dari penyebut pecahan yang dijumlah atau dikurangkan.

\section{Simpulan dan Saran}

Langkah pembelajaran yang belum pernah dikenal para siswa memunculkan rasa ingin tahu tentang kelanjutan langkah yang akan dihadapi. Rasa keingintahuan mendorong siswa tetap berkonsentrasi dan dengan penuh semangat melaksanakan tugas-tugas yang dihadirkan. Temuan ini mengisyaratkan bahwa para guru dituntut kreativitasnya dalam merancang langkah-langkah pembelajaran untuk menciptakan langkah pembelajaran yang mampu memberikan nuansa baru dalam proses pembelajaran.

Model STAD menuntut terjadinya tutor sejawat selama proses pembelajaran. Sebelum proses pembelajaran, guru telah memberi gambaran tentang tugas dan tanggung jawab siswa dalam kerja kelompok. Tugas sebagai tutor sejawat mendorong para siswa mencari bekal pengetahuan di luar proses pembelajaran, yaitu tentang cara menjumlah dan mengurangkan bilangan pecahan. Dengan bekal yang telah diperoleh sebelum proses pembelajaran, tuntunan proses penjumlahan dan pengurangan bilangan pecahan yang disuguhkan melalui e-learning mudah dipahami dan diterapkan para siswa dalam latihan dan evaluasi pembelajaran. Temuan ini mengisyaratkan bahwa sebaiknya para siswa diberikan gambaran tentang proses pembelajaran yang akan dilakukan esok hari supaya siswa bisa mengetahui dan bila dirasa perlu mempelajari dahulu di luar proses pembelajaran.

Analisis terhadap lembar jawab siswa menunjukkan bahwa semua siswa bisa melakukan proses penjumlahan dan pengurangan pecahan. Kesalahan yang dilakukan para siswa bukan berasal dari ketidaktahuan proses penjumlahan dan pengurangan pecahan melainkan dari kurangtelitian siswa dalam bermain angka. Temuan ini mengisyaratkan bahwa guru perlu mengingatkan siswa tentang perlunya memeriksa kembali jawaban. Pengingatan perlu diberikan secara rinci, misalnya "Ayo teliti kembali KPK antara bilangan penyebut 3 dan 7 di soal nomor 4", "Ingat bila penyebut dikalikan 3 maka pembilangnya juga dikalikan 3".

\section{Daftar Pustaka}

Arikunto, S. 2014. Prosedur Penelitian Suatu Pendekatan Praktik. Jakarta: Rineka Cipta.

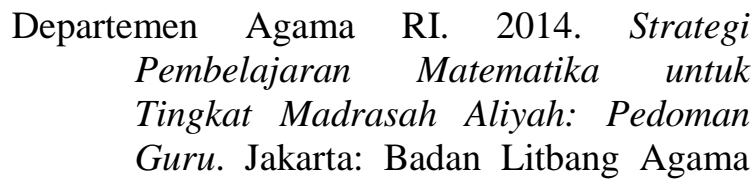

http://jurnal.unimus.ac.id/index.php/JPMat/index 
Jurnal Karya Pendidikan Matematika Vol 5 No 2 (2018) E ISSN : 2549 - 8401 P ISSN : 2339-2444

dan Diklat Keagamaan Pusdiklat Tenaga Teknis Keagamaan.

Sardiman. 2007. Interaksi dan Motivasi Belajar Mengajar, Jakarta: Raja Grafindo Persada.

Soekartawi. 2010. E-Learning: Konsep dan Aplikasinya. BahanCceramah/Makalah disampaikan pada
Seminar yang diselenggarakan oleh Balitbang Depdiknas, Jakarta, 18 Desember 2010.

Triyono, Lovi. 2012. Urgensi Penggunaan dan Pengembangan Teknologi Informatika Dalam Pendidikan (E-Learning). Bandung:UPI. 